\title{
Absorption, Distribution, Metabolism, and Excretion of the Oral Prostaglandin D2 Receptor 2 Antagonist Fevipiprant (QAW039) in Healthy Volunteers and In Vitro ${ }^{\text {[ }}$
}

\author{
David Pearson, H. Markus Weiss, Yi Jin, Jan Jaap van Lier, Veit J. Erpenbeck, Ulrike Glaenzel, \\ Peter End, Ralph Woessner, Fabian Eggimann, and Gian Camenisch
}

Novartis Institutes for Biomedical Research, Novartis Pharma AG, Basel, Switzerland (D.P., H.M.W., Y.J., V.J.E., U.G., P.E., R.W., F.E., G.C.); PRA International, Early Development Services, Zuidlaren, the Netherlands (J.J.v.L.)

Received February 2, 2017; accepted April 20, 2017

\section{ABSTRACT}

Fevipiprant is a novel oral prostaglandin $D_{2}$ receptor $2\left(D_{2}\right.$; also known as CRTh2) antagonist, which is currently in development for the treatment of severe asthma and atopic dermatitis. We investigated the absorption, distribution, metabolism, and excretion properties of fevipiprant in healthy subjects after a single $200-\mathbf{m g}$ oral dose of $\left[{ }^{14} \mathrm{C}\right]$-radiolabeled fevipiprant. Fevipiprant and metabolites were analyzed by liquid chromatography coupled to tandem mass spectrometry and radioactivity measurements, and mechanistic in vitro studies were performed to investigate clearance pathways and covalent plasma protein binding. Biotransformation of fevipiprant involved predominantly an inactive acyl glucuronide (AG) metabolite, which was detected in plasma and excreta, representing $\mathbf{2 8} \%$ of excreted drug-related material. The AG metabolite was

\section{Introduction}

The prevalence of allergic diseases is increasing worldwide, with the World Health Organization estimating that 400 million people globally will be asthma sufferers by 2025 (Pawankar, 2014). In the European Union, 44-76 million individuals of the 217 million European Union employees suffer from allergic diseases of the airways or the skin and up to $90 \%$ of these individuals are untreated or insufficiently treated (Zuberbier et al., 2014).

Part of this work was previously presented as follows: Pearson D, Jin Y, Erpenbeck VE, Woessner R, Camenisch G, Weiss HM. (2006) Absorption, metabolism and excretion of fevipiprant (QAW039) investigated in vivo and in vitro. European Respiratory Society International Congress; 2016 Sept 3-7; London, United Kingdom. European Respiratory Society, Lausanne, Switzerland.

D.P., M.W., Y.J., V.E., U.G., P.E., R.W., F.E., and G.C. are employees of Novartis Pharma and may hold shares in Novartis.

https://doi.org/10.1124/dmd.117.075358.

S This article has supplemental material available at dmd.aspetjournals.org. found to covalently bind to human plasma proteins, likely albumin; however, in vitro covalent binding to liver protein was negligible. Excretion was predominantly as unchanged fevipiprant in urine and feces, indicating clearance by renal and possibly biliary excretion. Fevipiprant was found to be a substrate of transporters organic anion transporter 3 (OAT3; renal uptake), multidrug resistance gene 1 (MDR1; possible biliary excretion), and organic anion-transporting polypeptide 1B3 (OATP1B3; hepatic uptake). Elimination of fevipiprant occurs via glucuronidation by several uridine 5'-diphospho glucuronosyltransferase (UGT) enzymes as well as direct excretion. These parallel elimination pathways result in a low risk of major drug-drug interactions or pharmacogenetic/ethnic variability for this compound.

ABBREVIATIONS: ADME, absorption, distribution, metabolism, and excretion; $\mathrm{AE}$, adverse event; $\mathrm{Ae}_{0-240 \mathrm{~h}}$, amount of drug excreted into the urine from time 0 to 240 hours after the dose; AG, acyl-glucuronide; AUC, area under the concentration-time curve; $A U C_{0-t}$, area under the concentration-time curve from time 0 to $t ; \mathrm{AUC}_{\text {inf, }}$, area under the concentration-time curve from time 0 to infinity; CL/F, systemic clearance of the drug from the plasma divided by bioavailability; $\mathrm{CL}_{\mathrm{r}}$, renal clearance; $\mathrm{DDI}$, drug-drug interaction; $\mathrm{DP}_{2}$, prostaglandin $\mathrm{D}_{2}$ receptor $2 ; f_{\mathrm{u}}$, fraction unbound; GSH, glutathione; LC-MS/MS, liquid chromatography coupled to tandem mass spectrometry; LSC, liquid scintillation counting; MATE, multidrug and toxin extrusion protein; MDR, multidrug resistance gene; OAT, organic anion transporter; OATP, organic anion-transporting polypeptide; PBS, phosphate-buffered saline; PK, pharmacokinetic(s); QAW039, fevipiprant, [(2-[2-methyl-1-(4-[methylsulfonyl]-2-[trifluoromethyl]benzyl)-1H-pyrrolo(2,3-b)pyridin-3-yl] acetic acid; SEC, size exclusion chromatography; $T_{\max }$, time to reach peak or maximum concentration after drug administration; $T_{1 / 2}$, terminal half-life of elimination; UDPGA, uridine $5^{\prime}$-diphosphoglucuronic acid; UGT, uridine $5^{\prime}$-diphospho (UDP)glucuronosyltransferase; $V z / F$, apparent volume of distribution during terminal phase divided by bioavailability. 
Two phase 1 studies investigated the pharmacokinetics (PK), safety, and tolerability of fevipiprant after single and multiple ascending doses in healthy subjects (Erpenbeck et al., 2016). On administration of single and multiple oral doses, fevipiprant peak plasma concentrations were observed 1-3 hours after the dose, and the apparent terminal half-life was approximately 20 hours. Steady state was achieved within 4 days, with less than 2-fold accumulation. An acyl-glucuronide (AG) metabolite without $\mathrm{DP}_{2}$ antagonist activity was detected in plasma. Fevipiprant was well-tolerated at single and multiple oral doses up to $500 \mathrm{mg} /$ day (Erpenbeck et al., 2016).

With any new chemical entities, it is important to identify and quantify all relevant metabolites and elimination pathways for assessment of possible metabolite pharmacology, safety (CDER, 2008; ICH, 2009; Gao et al., 2013), clearance mechanisms, and drug-drug interactions (DDIs) (CDER, 2012; CHMP, 2012), including planning of suitable clinical DDI and hepatic/renal impairment studies. We report the assessment of human absorption, distribution, metabolism, and excretion (ADME) of a single oral $200-\mathrm{mg}$ dose of $\left[{ }^{14} \mathrm{C}\right]$-fevipiprant in healthy male subjects, as well as identification of enzymes and transporters involved in the human PK of fevipiprant, and characterization of covalent binding to plasma proteins in humans.

\section{Materials and Methods}

The primary objectives of the clinical ADME study were to identify and quantify fevipiprant and metabolites in plasma and excreta for analysis of absorption, $\mathrm{PK}$, and elimination pathways.

\section{Study Drug}

The parent batch of $\left[{ }^{14} \mathrm{C}\right]$-radiolabeled fevipiprant was prepared by the Isotope Laboratory, Drug Metabolism and Pharmacokinetics, Novartis, Switzerland. This batch was adjusted to a final specific radioactivity of $15.7 \mathrm{kBq} / \mathrm{mg}$ by dilution with nonradiolabeled fevipiprant, produced under Good Manufacturing Practice and released for human use by Technical Research and Development, Novartis. The chemical structure of the compound and the position of the radiolabel are shown in Fig. 1.

Chemical and radiochemical purity $99.0 \%$ (with no single impurity $\geq 1 \%$ ) was verified by high-performance liquid chromatography, and stability was

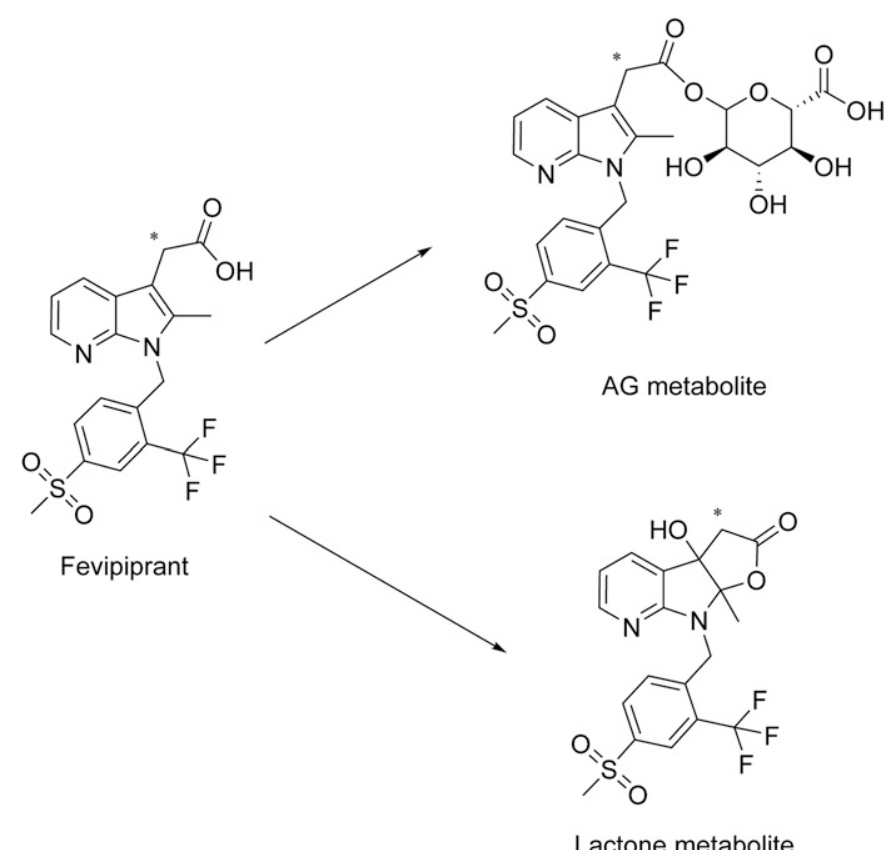

Fig. 1. Structural formula of fevipiprant and proposed biotransformation pathways of fevipiprant in humans. *Position of $\left[{ }^{14} \mathrm{C}\right]$-radiolabel. ascertained from the period from manufacturing to dose administration. The radiolabeled study drug was provided as individually manufactured doses of four 50-mg (monohydrate; $787.5 \mathrm{kBq}$ ) $\left[{ }^{14} \mathrm{C}\right]$-fevipiprant capsules per bottle providing a total radioactive dose of $3.15 \mathrm{MBq}$ (Isotope Laboratory and Technical Research and Development, Novartis).

\section{Chemicals and Standards}

Radiolabeled and nonradiolabeled fevipiprant, radiolabeled and nonradiolabeled AG metabolite, and nonradiolabeled lactone metabolite were synthesized as described in Bala et al. (2005) and the Supplemental Data. All other reagents were of analytic grade and obtained from commercial sources.

\section{Subjects and Study Design}

This was an open-label, single-center, single-arm study to investigate the ADME of a single oral dose of $200-\mathrm{mg}\left[{ }^{14} \mathrm{C}\right]$-fevipiprant in four healthy male subjects. Informed consent was obtained from each subject in writing before any assessment was performed. The study (registered with EudraCT as 2011-00284210) was conducted at PRA International, Early Development Services, Zuidlaren, the Netherlands, from February 17 through March 26, 2012, according to the ethics principles of the Declaration of Helsinki. The study protocol was reviewed by the independent ethics committee of Stichting Beordeling Ethiek Biomedisch Onderzoek, Assen, the Netherlands.

Subjects were male, aged 18 to 55 years, weighed $\geq 50 \mathrm{~kg}$, with a body mass index of $18-29 \mathrm{~kg} / \mathrm{m}^{2}$, and could communicate well with the investigator, and understand and comply with the requirements of the study. The subjects were nonsmokers, had no history of alcoholism or drug abuse, and did not use any prescription drugs or herbal medication within 4 weeks before dosing and/or overthe-counter medication or dietary supplements (vitamins included) within 2 weeks before dosing.

The study consisted of a screening visit (between days -14 and -2 ), a baseline visit (on day -1), a single-dose treatment (on day 1), 240 hours in-house observation period (days 1-11), optional collections and assessments (at days 14 and 21), and a study completion visit (day 25). Each subject received a single oral $\left[{ }^{14} \mathrm{C}\right]$-radiolabeled dose of $200 \mathrm{mg}$ fevipiprant $(3.15$ $\mathrm{MBq}, 85 \mu \mathrm{Ci}$ ), as four $50-\mathrm{mg}$ capsules in the morning after an overnight fast of at least 10 hours. Subjects continued to fast for 4 hours after dosing (water was allowed after 2 hours).

The radiation exposure was not deemed to pose any relevant health risk to the subjects. Based on human PK data (with nonradiolabeled fevipiprant) and animal mass balance data (with $\left[{ }^{14} \mathrm{C}\right]$-fevipiprant), the expected effective radiation dose was estimated to be up to $0.87 \mathrm{mSv}$, lower than the recommended limit of $1 \mathrm{mSv} / \mathrm{yr}$ defined by the International Commission on Radiologic Protection (ICRP, 2007). It was not expected that the clinical and laboratory staff handling the radioactive materials and samples would be exposed to any radiation and associated health risk.

Safety assessments included the monitoring and recording of all adverse events (AEs), regular checks of routine blood chemistry, hematology and urine values, electrocardiogram recordings, measurements of vital signs, and physical examinations.

Sample Collection and Aliquoting. Samples of whole blood, urine, and feces were collected over an 11-day period. Part of each whole blood sample was processed to plasma. Each urine and plasma sample was divided into two parts, and one part of each sample was acidified by addition of $1 \%$ volume of a $70 \%$ lactic acid solution to stabilize the known AG metabolite. Details of sample collection and processing are given in the Supplemental Data.

\section{Quantification of Total Radioactivity, Fevipiprant, and Metabolites}

The total radioactivity in blood, nonacidified plasma, nonacidified urine, and feces was measured by liquid scintillation counting (LSC). Concentrations of fevipiprant and AG metabolite in all acidified plasma samples up to 240 hours after the dose and in acidified urine were assessed by a validated specific liquid chromatography with tandem mass spectrometry (LC-MS/MS) assay. The AG metabolite was quantified as the sum of all isomers formed by AG rearrangement. Fevipiprant and metabolites were analyzed in acidified plasma, acidified urine, and feces extract pools of individual subjects by LC-MS/MS with offline radioactivity detection. Selected plasma samples were analyzed by size exclusion 
TABLE 1

PK parameters of total radioactivity in whole blood and plasma and of fevipiprant and its main circulating metabolite (AG metabolite) in plasma

Values are mean \pm S.D.

\begin{tabular}{|c|c|c|c|c|}
\hline \multirow{2}{*}{ Parameter } & \multicolumn{2}{|c|}{ Total Radioactivity } & \multicolumn{2}{|c|}{ Plasma } \\
\hline & Whole Blood & Plasma & Fevipiprant & AG Metabolite \\
\hline$T_{\max }(\mathrm{h})^{a}$ & $3.00(3.00-6.00)$ & $3.00(3.00-6.00)$ & $2.50(2.00-6.00)$ & $3.00(3.00-6.00)$ \\
\hline$C_{\max }(\mathrm{ng} / \mathrm{ml} \text { or } \mathrm{ng}-\mathrm{eq} / \mathrm{ml})^{b}$ & $923 \pm 216$ & $1750 \pm 396$ & $348 \pm 139$ & $1020 \pm 247$ \\
\hline $\mathrm{AUC}_{0-240 \mathrm{~h}}\left(\mathrm{ng}{ }^{*} \mathrm{~h} / \mathrm{ml} \text { or ng-eq* } \mathrm{h} / \mathrm{ml}\right)^{c}$ & $36,400 \pm 6960$ & $76,500 \pm 9740$ & $2490 \pm 312$ & $6890 \pm 1240$ \\
\hline $\mathrm{AUC}_{\mathrm{inf}}(\mathrm{ng}-\mathrm{eq} * \mathrm{~h} / \mathrm{ml})$ & $69,700 \pm 10,600$ & $156,000 \pm 20,700$ & - & - \\
\hline $\mathrm{CL} / F(\mathrm{l} / \mathrm{h})$ & - & - & $80.5 \pm 9.42$ & - \\
\hline $\mathrm{Vz} / F(1)$ & - & - & $1370 \pm 459$ & - \\
\hline$T_{1 / 2}(\mathrm{~h})$ & $230 \pm 54.6$ & $254 \pm 24.8$ & $12.3 \pm 5.95$ & $11.8 \pm 5.19$ \\
\hline
\end{tabular}

${ }^{a} T_{\max }$ is presented as median (range).

${ }^{b}$ Units are $\mathrm{ng} / \mathrm{ml}$ for fevipiprant and AG metabolite, and $\mathrm{ng}$-eq/ml for total radioactivity.

${ }^{c}$ Units are $\mathrm{ng} * \mathrm{~h} / \mathrm{ml}$ for fevipiprant and AG metabolite, and ng-eq*h/ml for total radioactivity.

chromatography (SEC) with offline radioactivity detection. Details of these analytic methods are provided in the Supplemental Data.

\section{Structural Characterization of Metabolites}

The structural characterization of metabolites in plasma and excreta was performed by tandem mass spectrometry analysis after liquid chromatographic separation of analytes (described earlier).

Single stage and product ion spectra with exact mass measurements were obtained in positive ion mode. The structures of the metabolites were derived from their product ion mass spectra, the elemental composition determined by exact mass measurement and comparison with synthetic standards.

\section{PK Evaluations}

The present study evaluated the following PK parameters, which were determined from blood (total radioactivity), plasma, and urine: $C_{\max }$ (the maximum [peak] plasma or blood drug concentration after single administration [amount $\times$ volume $^{-1}$ ]), $T_{\max }$ (the time to reach peak or maximum concentration following drug administration [time]), $T_{1 / 2}$ (the elimination half-life associated with the terminal slope [lambda $z$ ], respectively, of a semilogarithmic concentration-time curve [time]), $\mathrm{AUC}_{0-t}$ (the area under the concentrationtime curve from time 0 to $t$ [amount $\times$ time $\times$ volume $^{-1}$ ]), $\mathrm{AUC}_{\text {inf }}$ (the area under the concentration-time curve from time 0 to infinity [amount $\times$ time $\times$ volume $^{-1}$ ]), $\mathrm{CL} / F$ (the systemic clearance of the drug from the plasma [volume $\times$ time $^{-1}$ ] divided by the bioavailability $F$ ), $V z / F$ (the apparent volume of distribution during the terminal [lambda $z$ ] phase divided by the bioavailability $F$ [volume]), $\mathrm{Ae}_{0-240 \mathrm{~h}}$ (amount of drug excreted into the urine from time 0 to 240 hours after the dose [\% of dose]), and $\mathrm{CL}_{\mathrm{r}}$ (renal clearance; calculated as $A e_{0-240 \mathrm{~h}} / \mathrm{AUC}_{0-240 \mathrm{~h}}$ ). The PK parameters were calculated using Phoenix WinNonlin 6.3 (Certara USA, Princeton, NJ) with noncompartmental analysis.

\section{In Vitro Investigations}

Fevipiprant Covalent Binding Assay in Microsomes and Hepatocytes. $\left[{ }^{14} \mathrm{C}\right]$-fevipiprant $(5 \mu \mathrm{M}, 4.9 \mathrm{MBq} / \mathrm{mg})$ was incubated with human liver microsomes $(0.5 \mathrm{mg} / \mathrm{ml})$ at $37^{\circ} \mathrm{C}$ in sodium phosphate buffer $(0.1 \mathrm{M}, \mathrm{pH} 7.4)$ in the presence of several sets of cofactors: 1) glutathione [GSH, $5 \mathrm{mM}$; 2) $\beta$-nicotinamide adenine dinucleotide phosphate [NADPH, $1 \mathrm{mM}$ ]; 3) NADPH and uridine 5 '- diphosphoglucuronic acid [UDPGA, $4 \mathrm{mM}$ ]; and 4) NADPH, UDPGA, and GSH. Aliquots were taken after 1 hour and precipitated with 3 volumes of acetonitrile.

$\left[{ }^{14} \mathrm{C}\right]$-fevipiprant $(10 \mu \mathrm{M}, 4.9 \mathrm{MBq} / \mathrm{mg})$ was incubated with cryopreserved human hepatocytes $\left(0.5 \times 10^{6}\right.$ cells $\left./ \mathrm{ml}\right) 37^{\circ} \mathrm{C}, 95 \%$ humidity and $5 \% \mathrm{CO}_{2}$, in Williams' E medium. Aliquots were taken after $0,1.5$, and 3 hours and were precipitated with 4 volumes of acetonitrile.

The precipitate obtained from each experiment was filtered and washed extensively with $90 \%$ methanol, then the filters were removed and protein precipitate was solubilized in Solvable (PerkinElmer, Waltham, MA), then analyzed by LSC. Covalent protein binding was calculated as $\mathrm{pmol} / \mathrm{mg}$ protein and pmol $/ 10^{6}$ cells for microsomes and hepatocytes, respectively.

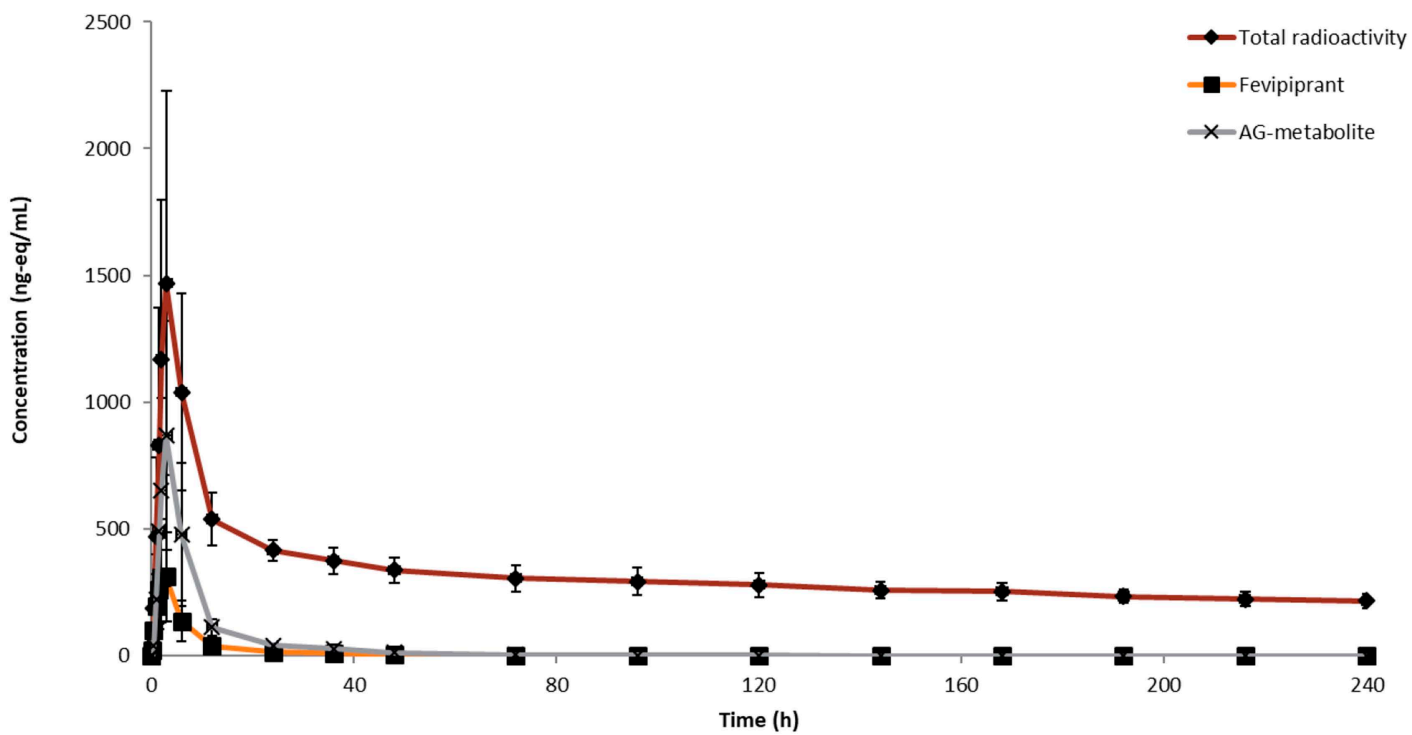

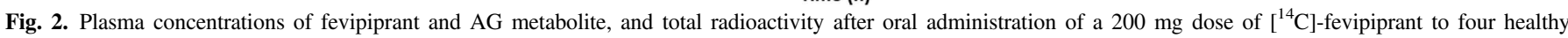

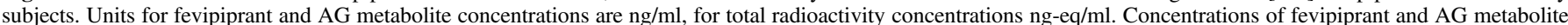
were determined by LC-MS/MS, and concentrations of total radioactivity were determined by LSC. 


\section{TABLE 2}

Fevipiprant and metabolites in plasma, based on metabolism profiles Values are presented as mean \pm S.D.

\begin{tabular}{lcc}
\hline \multirow{2}{*}{ Component } & \multicolumn{2}{c}{$\left[{ }^{14} \mathrm{C}\right]-\mathrm{AUC}_{0-12 \mathrm{~h}}{ }^{a}$} \\
\cline { 2 - 3 } & $\mathrm{ng} / \mathrm{ml}$ or ng-eq*h/ml ${ }^{b}$ & $\%$ of Total \\
\hline Fevipiprant & $1690 \pm 266$ & $15.3 \pm 2.33$ \\
AG metabolite & $6240 \pm 922$ & $56.5 \pm 5.65$ \\
P8.5 & $125 \pm 145$ & $1.18 \pm 1.37$ \\
Sum of additional components & $47.1 \pm 52.9$ & $0.405 \pm 0.426$ \\
Total components detected & $8100 \pm 852$ & $73.4 \pm 2.73$ \\
Lost during sample processing & $2920 \pm 210$ & $26.6 \pm 2.73$ \\
Total radiolabeled components in sample & $11,000 \pm 837$ & 100 \\
\hline
\end{tabular}

${ }^{a}$ Calculated using the linear trapezoidal method; concentrations at time zero taken as zero. ${ }^{b}$ Units are $\mathrm{ng} / \mathrm{ml}$ for fevipiprant, and $\mathrm{ng}$-eq/ml for other components.

Incubations of Radiolabeled Fevipiprant and AG Metabolite with Human Plasma. $\left[{ }^{14} \mathrm{C}\right]$-fevipiprant $(4.9 \mathrm{MBq} / \mathrm{mg})$ and $\left[{ }^{14} \mathrm{C}\right]-\mathrm{AG}$ metabolite (3.3 MBq/mg) were each incubated with 1:1 human plasma/phosphate-buffered saline (PBS) at a final concentration of $20 \mu \mathrm{M}$ at $37^{\circ} \mathrm{C}$ for 24 hours. Incubation of $\left[{ }^{14} \mathrm{C}\right]-\mathrm{AG}$ metabolite at $100 \mu \mathrm{M}$ and control incubations without plasma were also performed. During the $20 \mu \mathrm{M}$ incubations, aliquots were removed, precipitated by addition of 5 volumes of acetonitrile and incubation at $4{ }^{\circ} \mathrm{C}$ for 60 minutes, and filtered. Filters were washed with methanol/water (90:10) until the eluate contained less than $5 \mathrm{pmol} / \mathrm{ml}$ radioactivity, as measured by LSC. Retained radioactivity in the filters was then measured by dissolution of filters in Solvable (PerkinElmer) at room temperature for 16 hours, followed by addition of $\mathrm{HCl}$ ( $1 \mathrm{M}, 0.25 \mathrm{ml})$; then scintillant ( $5 \mathrm{ml}$, Irgasafe plus; Zinsser Analytic, Frankfurt, Germany) was added, and radioactivity was measured by LSC. Retained radioactivity was assumed to be bound to proteins.

Aliquots from 21-hour incubations were further analyzed by SDS-PAGE. We prepared 5, 10, and $20 \mu \mathrm{g}$ aliquots in XT sample buffer (Bio-Rad Laboratories, Hercules, CA) supplemented with $10 \mathrm{mM}$ DTT and heated them at $95^{\circ} \mathrm{C}$ for 5 minutes. Subsequently, prepared samples were loaded to a Criterion XT precast gradient Midi gel 4\%-12\% Bis Tris (Bio-Rad Laboratories). The gel was run for 35 minutes at 200 Volt in Mes buffer (Bio-Rad Laboratories). The gel was blotted to a polyvinylidene fluoride membrane (Transblot Turbo; Bio-Rad Laboratories), and the resulting membrane was exposed for 4 days to a radioimaging plate (BAS-IP TR 2040; Fujifilm, Tokyo, Japan) to detect the radiolabeled proteins. Molecular weight and intensities of detected bands were measured by labeling the size marker (all blue standard; Bio-Rad Laboratories) on the membrane with $3 \mathrm{H}$ supplemented ink and the analysis tool of the AIDA software (v.4.25One; FinalWire, Budapest, Hungary).

Additionally, aliquots from 21-hour incubations were depleted of albumin and analyzed by SDS-PAGE. We purified $10 \mu \mathrm{l}$ aliquots of $20 \mu \mathrm{M}$ incubations using ProteoExtract Albumin Removal Kit (cat. no. 122640; Calbiochem, San Diego, CA). Sample aliquots were diluted with albumin Binding Buffer $(350 \mu \mathrm{l})$ and were purified according to the kit manual. The volumes of each eluate were reduced to $110 \mu \mathrm{l}$ by centrifuging at $14,000 \mathrm{~g}$ in $30 \mathrm{kDa}$ Amicon spin filters (Millipore, Billerica, MA). Protein content of the samples was determined using the Protein DC Assay (Bio-Rad Laboratories) and a bovine serum albumin standard in PBS. Samples were then analyzed by SDS-PAGE, as already described.

SDS-PAGE gels were additionally analyzed by gel excision and protein characterization as follows. The radiolabeled band was excised and digested with trypsin, as described in the In-gel tryptic digestion kit (Thermo Fisher Scientific, Waltham, MA) procedure. The bands were first destained, reduced, alkylated, and washed, as recommended in the procedure before digestion. Digestions with trypsin and chymotrypsin were performed in ammonium bicarbonate $(500 \mathrm{mM}, \mathrm{pH} 8.0)$ for 24 hours at $37^{\circ} \mathrm{C}$. After incubation, incubates were acidified by adding $1 \%$ volume of lactic acid ( $70 \%$ in water). Acidified incubates were analyzed by LC-MS/MS with an Acuity I class system (Waters Corporation, Milford, MA). Samples were injected onto an Acuity BEH130 C18 column $(150 \times 2.1 \mathrm{~mm}, 1.7 \mu \mathrm{m}$ particles; Waters $)$ with a corresponding guard column $(10 \times 2.1 \mathrm{~mm})$, heated to $30^{\circ} \mathrm{C}$. Separation was performed with a gradient of mobile phases formic acid $(0.1 \%$; phase A) and acetonitrile (phase B) at a flow rate of $0.2 \mathrm{ml} / \mathrm{min}$ The gradient was as follows:
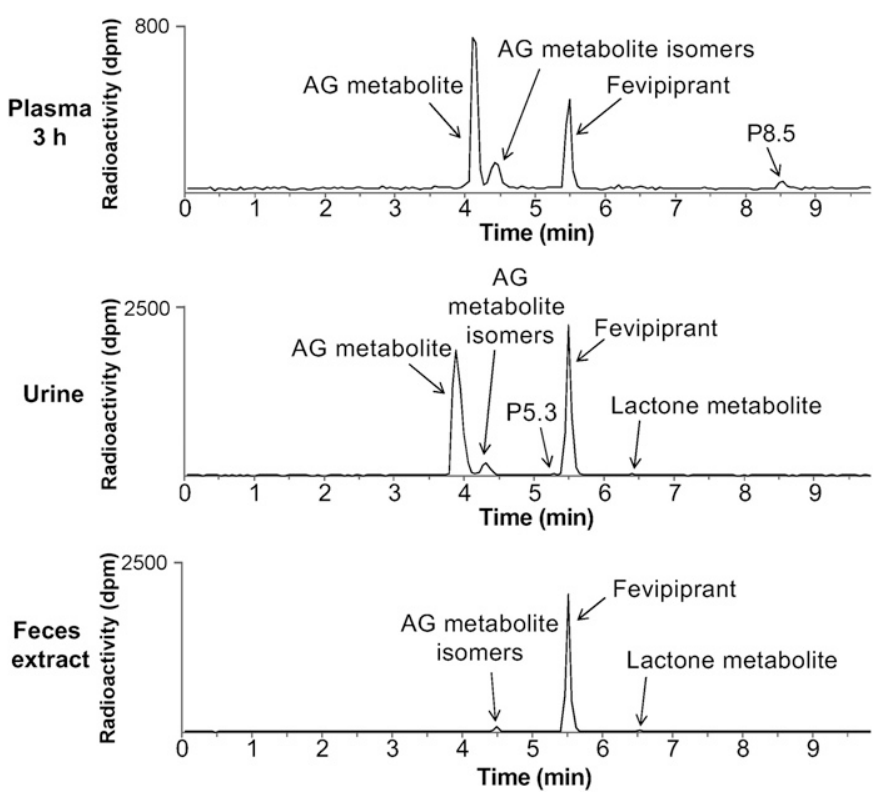

Fig. 3. Representative radiochromatograms in plasma ( 3 hours after dose), urine (time pooled 0-72 hours), and feces extracts (time pooled 0-96 hours) for one subject after oral administration of a $200-\mathrm{mg}$ dose of $\left[{ }^{14} \mathrm{C}\right]$-fevipiprant. dpm: disintegrations per minute.

0 to 2 minutes, $5 \% \mathrm{~B} ; 2$ to 70 minutes, 5 to $50 \% \mathrm{~B} ; 70$ to 75 minutes, 50 to $75 \%$ $\mathrm{B} ; 75$ to 76 minutes, 75 to $5 \% \mathrm{~B}$; and 76 to 86 minutes, $5 \% \mathrm{~B}$. The eluate was directed to an LTQ-Orbitrap XL mass spectrometer (Thermo Fisher Scientific) for tandem mass spectrometry analysis. Protein fingerprint analysis was then performed using ProteinProspector MS-Fit software version 2 (University of California-San Francisco, http://prospector.ucsf.edu/prospector/mshome. htm).

Aliquots from the 24-hour $100 \mu \mathrm{M}$ incubation of the AG metabolite were analyzed by SEC, as described for plasma samples (Supplemental Data).

Other In Vitro Methods. Descriptions of all other in vitro methods are provided in the Supplemental Data.

\section{Demographics}

A total of four male Caucasian subjects were enrolled, and all completed the study. Subjects had a mean age of 43.0 years (range: $27-54$ years), weight of $85.6 \mathrm{~kg}$ (range: $77.9-93.5 \mathrm{~kg}$ ), height of $183.3 \mathrm{~cm}$ (range: $176-192 \mathrm{~cm}$ ), and body mass index of $25.5 \mathrm{~kg} / \mathrm{m}^{2}$ (range: $23.8-28.3 \mathrm{~kg} / \mathrm{m}^{2}$ ). Only male subjects were selected to perform a detailed analysis in a well-defined uniform group, and as the study size is insufficient to make statistical comparisons of subpopulations such as genders. No significant differences in PK or metabolism are known or anticipated between males and females.

\section{Results}

Safety and Tolerability Data. Two (50\%) of the subjects reported a total of four AEs during the study, which were considered to be mild in severity. There were no serious AEs or discontinuations due to AEs. Two AEs (headache and somnolence) were considered to be treatment related. No clinically significant abnormalities or changes were observed in clinical laboratory assessments, vital signs, or electrocardiogram parameters.

PK of Total Radioactivity, Fevipiprant, and AG Metabolite. Key PK variables calculated for total radioactivity, fevipiprant, and AG metabolite are summarized in Table 1 and Fig. 2. Values for AG metabolite represent the sum of AG metabolite and all isomers formed by AG rearrangement (assigned by comparison with rearrangement products formed from synthetic AG metabolite). 
After oral administration of $\left[{ }^{14} \mathrm{C}\right]$-fevipiprant, the levels of radioactivity in blood and plasma, and levels of fevipiprant and the AG metabolite in plasma were initially aligned and reached a maximum at approximately 3 hours after the dose. Radioactivity was detectable in blood and plasma for up to 240 hours after the dose, with a mean terminal half-life in plasma of 254 hours ( 230 hours in blood). Contrastingly, fevipiprant and its major metabolite, the AG metabolite, were only detected in plasma up to 96 and 120 hours after the dose, respectively, with average half-lives of approximately 12 hours. The total exposure ( $\mathrm{AUC}_{0-240 \mathrm{~h}}$ ) and $C_{\max }$ of radioactivity in plasma were approximately 2-fold higher than observed in blood, indicating that blood radioactivity was almost entirely located in plasma. Intersubject variability was low to moderate.

Metabolite Identification and Profiles, and Metabolite PK Analysis. Plasma, urine, and feces extracts were analyzed by LC-MS/ MS with radioactivity detection for metabolite identification and profiles. The structures of all identified metabolites, which could be confirmed by comparison of retention time and mass spectral data with synthesized standards, are given in Fig. 1. Mass spectral data and representative product ion mass spectra of fevipiprant and metabolites are shown in Supplemental Table 1 and Supplemental Fig. 1. The only abundant metabolite detected was the AG metabolite. A minor lactone metabolite was also identified, likely resulting from oxidative ringclosure of fevipiprant (see the discussion section for more detail). The structures of minor components P5.3 and P8.5 could not be determined.

Metabolite profiles were determined after extraction of samples by solid phase extraction. The extraction recoveries of total radioactivity were found to decrease with time after the dose for all subjects. The average percentage of total radioactivity recovery at 2 hours was $92.6 \%$, but at 48 hours was only $11.0 \%$. Due to the low extractable radioactivity in plasma samples at later time points, radiochromatograms were only analyzed up to 12 hours after the dose.

Exposure (as $\mathrm{AUC}_{0-12 \mathrm{~h}}$ ) of fevipiprant and its metabolites, based on the radiochromatogram profiles, is shown in Table 2. A representative plasma radiochromatogram for one subject is shown in Fig. 3. The AG metabolite and fevipiprant represented the main proportion of radioactivity in plasma (total $72 \%$ of $\left[{ }^{14} \mathrm{C}\right]-\mathrm{AUC}_{0-12 \mathrm{~h}}$ ) based on radiochromatograms up to 12 hours. However, fevipiprant and the $\mathrm{AG}$ metabolite accounted for a much lower proportion of the total plasma $\left[{ }^{14} \mathrm{C}\right]-\mathrm{AUC}_{0-240 \mathrm{~h}}$ (around 12\%) based on LC-MS/MS quantification up to 240 hours (Table 1). Correspondingly, the loss of radioactivity observed during sample processing represented a major proportion of radioactivity, amounting to $26.6 \% \pm 2.7 \%$ of the plasma $\left[{ }^{14} \mathrm{C}\right]-\mathrm{AUC}_{0-12} \mathrm{~h}$, and was estimated at $90.4 \%$ of the plasma $\left[{ }^{14} \mathrm{C}\right]-\mathrm{AUC}_{0-240 \mathrm{~h}}$ based on LC-MS/MS quantification of fevipiprant and the AG metabolite. To further investigate the loss of radioactivity during sample processing,

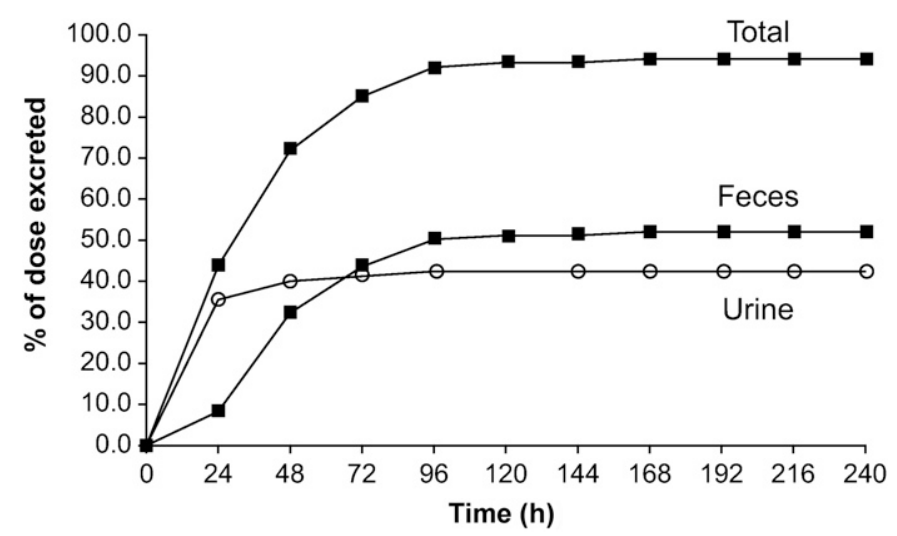

Fig. 4. Cumulative excretion of radioactivity in urine and feces after oral administration of a 200-mg dose of $\left[{ }^{14} \mathrm{C}\right]$-fevipiprant to four healthy subjects. Radioactivity was determined by LSC.

additional plasma analyses and in vitro experiments were performed (see the section "Covalent Binding and Acyl-Glucuronide Stability Investigations").

Excretion of Radiolabeled Components. After oral administration of $\left[{ }^{14} \mathrm{C}\right]$-fevipiprant, $42.1 \% \pm 4.3 \%$ of the dose was recovered in urine, and $51.9 \% \pm 4.8 \%$ was recovered in feces over 240 hours after the dose (Supplemental Table 2; Fig. 4), indicating that radioactive drug-related material was primarily excreted via renal and biliary/fecal excretion. The overall recovery of drug-related material was near complete $(93.9 \% \pm$ $2.6 \%$ ). The majority of the radioactivity was recovered within 144 hours after the dose, with subsequent samples up to 240 hours containing less than $1 \%$ of the dose.

Metabolite profiles were also determined in urine and feces pools (Fig. 3). Extraction recovery was high for all excreta samples (>88\%). Urinary and feces excretion data for fevipiprant and all metabolites based on metabolite profiles, and urinary excretion data for fevipiprant and the AG metabolite based on LC-MS/MS quantification over 240 hours are presented in Table 3.

In urine, fevipiprant and AG metabolite were the major components (total approximately $40 \%$ of dose). Urinary excretion data for fevipiprant and the AG metabolite over 240 hours were similar to the 0-72 hours values (Table 3 ). In feces, fevipiprant was the major component excreted. Overall, fevipiprant and AG metabolites represented approximately $85 \%$ of the dose excreted in urine and feces, and other metabolites were only present in traces.

Based on urinary excretion data for the period 0-240 hours (Table 3), the renal clearance of fevipiprant and AG metabolite were calculated to be $8.92 \mathrm{l} / \mathrm{h}$ and $7.99 \mathrm{l} / \mathrm{h}$, respectively. Absorption was estimated to be at

TABLE 3

Fevipiprant and metabolites in excreta

Values are presented as mean \pm S.D.

\begin{tabular}{|c|c|c|c|c|}
\hline \multirow{2}{*}{ Component } & \multicolumn{3}{|c|}{ Excretion (\% of Dose $)^{a}$} & \multirow{2}{*}{$\frac{\text { Excretion }(\% \text { of Dose })^{b}}{\text { Urine } 0-240 \mathrm{~h}}$} \\
\hline & Urine $0-72 \mathrm{~h}$ & Feces $0-96 \mathrm{~h}$ & Total & \\
\hline Fevipiprant & $12.7 \pm 2.21$ & $44.5 \pm 6.12$ & $57.2 \pm 6.29$ & $11.0 \pm 1.56$ \\
\hline AG metabolite & $26.9 \pm 2.58$ & $1.24 \pm 0.244$ & $28.1 \pm 2.40$ & $19.25 \pm 2.48$ \\
\hline Lactone metabolite & $0.133 \pm 0.0458$ & $0.177 \pm 0.355$ & $0.310 \pm 0.389$ & NA \\
\hline P5.3 & $0.0956 \pm 0.0121$ & 0.00 & $0.0956 \pm 0.0121$ & NA \\
\hline Total components detected & $39.8 \pm 3.35$ & $46.0 \pm 6.36$ & $85.7 \pm 5.16$ & NA \\
\hline Total excretion in time period $^{c}$ & $41.2 \pm 3.78$ & $50.5 \pm 6.26$ & $91.7 \pm 4.97$ & NA \\
\hline
\end{tabular}

NA, not available.

${ }^{a}$ Quantified from radioactivity profiles.

${ }^{b}$ Quantified by LC-MS/MS.

${ }^{c}$ The difference between total excretion and total components detected corresponds to losses during sample preparation. 
TABLE 4

Covalent binding of fevipiprant to microsomes and hepatocytes in vitro

\begin{tabular}{lc}
\hline \multicolumn{1}{c}{ Incubation Conditions } & Amount of Covalent Drug Protein Adducts \\
\hline HLM, GSH & $1 \pm 0.0 \mathrm{pmol} / \mathrm{mg}$ protein \\
HLM, NADPH & $3 \pm 0.4 \mathrm{pmol} / \mathrm{mg}$ protein \\
HLM, NADPH, UDPGA & $3 \pm 0.3 \mathrm{pmol} / \mathrm{mg}$ protein \\
HLM, NADPH, UDPGA, GSH & $1 \pm 0.5 \mathrm{pmol} / \mathrm{mg}$ protein \\
HH & $8 \pm 1.4 \mathrm{pmol} / 10^{6}$ cells \\
\hline
\end{tabular}

GSH, glutathione; HLM, human liver microsomes; HH, human hepatocytes; NADPH, nicotine adenine dinucleotide phosphate; UDPGA, uridine diphosphoglucuronic acid.

least $43.5 \%$, based on the total radioactive dose recovered from urine $(42.1 \%)$ and the metabolites excreted in feces (approximately $1.4 \%$ ).

Covalent Binding and Acyl-Glucuronide Stability Investigations. Due to the observed long retention of radioactivity in plasma and low extractability of plasma samples, we hypothesized that the AG metabolite could covalently bind to plasma proteins (Regan et al., 2010), leading to long-lived radioactive metabolite-protein conjugates, as observed for other compounds, such as ibuprofen (Castillo et al., 1995), tolmetin (Zia-Amirhosseini et al., 1994), and bilirubin (Weiss et al., 1983). Additional in vitro experiments were performed to investigate covalent binding. Initially, $\left[{ }^{14} \mathrm{C}\right]$-fevipiprant was incubated with human liver microsomes and human hepatocytes to investigate possible covalent binding of fevipiprant or metabolites to liver proteins mainly via oxidative processes. Additionally, incubations of $\left[{ }^{14} \mathrm{C}\right]$-fevipiprant and $\left[{ }^{14} \mathrm{C}\right]-\mathrm{AG}$ metabolite in human plasma were performed, followed by precipitation and LSC of proteins to identify whether radiolabeled protein conjugates were formed.

When probing for covalent binding of fevipiprant or metabolites to human liver microsomes and hepatocytes in the presence of various cofactors (Table 4) only trace levels of covalent binding were observed in comparison with positive control compounds. Additionally, no increase in covalent binding was observed with the addition of glucuronidation cofactor UDPGA, suggesting that covalent binding to liver microsomes associated with the AG metabolite is insignificant.

In incubations with plasma, fevipiprant showed very low covalent binding to human plasma proteins, while the AG metabolite showed 11-fold higher covalent binding after 24 hours' incubation (Supplemental Fig. 2), indicating that covalent binding in plasma occurs via the AG metabolite rather than the parent compound.

Subsequently, to identify proteins involved in plasma covalent binding, gel electrophoresis of the AG metabolite plasma incubate was performed. Radioimaging of the resulting gel (Fig. 5A, lanes A1-3) showed that only one protein of around $68 \mathrm{kDa}$ size was conjugated to the AG metabolite. Peptide fingerprint analysis of the labeled protein band by LC-MS after gel excision and trypsin/chymotrypsin digest identified that the abundant plasma protein human serum albumin was present. Based on this result, gel electrophoresis of AG metabolite plasma incubates after depletion of albumin was also performed. The intensity of the radio signal detected was significantly reduced by albumin depletion of the respective samples (Fig. 5A, lanes B1-3). These data show that the AG metabolite forms a conjugate with albumin in vitro.

To evaluate whether this in vitro finding corresponds to the in vivo observations, SEC of the AG metabolite plasma incubates and of the clinical plasma samples was performed (gel electrophoresis could not be performed on the in vivo samples, due to insufficient sensitivity). SEC of the AG metabolite in vitro incubation showed the presence of fevipiprant, AG metabolite, and an earlier eluting peak assigned to a protein conjugate (Fig. 5B). Analysis of in vivo human plasma samples showed similar profiles (representative samples are shown in Fig. 5C), with an increase of the protein conjugate peak over time after the dose. These data provide evidence that the in vivo plasma covalent binding also involves albumin.

The recoveries of radioactivity for all plasma samples analyzed by SEC were between $90 \%$ and $110 \%$, confirming that the low extraction recoveries for clinical plasma samples were explained by loss of drugrelated material covalently bound to plasma protein. Correspondingly, the amount of protein-conjugate detected by SEC at each time point was similar to the amount of radioactivity lost on extraction.

Acyl glucuronides are often unstable at neutral $\mathrm{pH}$ (Bailey and Dickinson, 2003) but can be stabilized by acidification of clinical samples (Ebner et al., 2010; Wang et al., 2011). As this instability was observed for the AG metabolite in preclinical experiments, an aliquot of all plasma and urine samples for analysis of fevipiprant and metabolites was acidified by addition of $1 \%$ volume of a $70 \%$ lactic acid solution. Experiments in blank urine samples showed that a $\mathrm{pH}$ in the range of 3.1-5.2 was obtained after acidification (compared with 5.3-7.3 before acidification), and the AG metabolite was confirmed to be stable to hydrolysis for 4 weeks at room temperature in acidified urine (less than $1 \%$ degradation to the parent compound measured). However, isomerization of the AG was not measured here, and may have occurred during the incubation. All clinical data reported here were obtained using the acidified aliquots, except for total radioactivity measurements.

To assess potential AG isomerization, incubations were performed with a synthesized standard of the 1-O-beta isomer of the AG metabolite to identify other AG isomers formed. Several isomers of the AG metabolite were detected and were assigned to AG rearrangement products (Bailey and Dickinson, 2003). As these isomers were considered to be degradation products of the AG metabolite that could not be accurately quantified if formed during sample collection or processing, they were quantified together with the AG metabolite for all analyses in this report.

Fevipiprant as a Substrate of Enzymes and Transporters. Based on the clinical excretion data, fevipiprant clearance pathways include glucuronidation and direct excretion of the parent drug. To determine which enzymes and transporters are involved in these processes, we performed a number of in vitro investigations.

To determine the enzymes catalyzing the formation of the AG metabolite, we investigated the in vitro biotransformation of $\left[{ }^{14} \mathrm{C}\right]$ fevipiprant, catalyzed by 12 recombinant uridine $5^{\prime}$-diphosphoglucuronosyltransferase (UDP-glucuronosyltransferase; UGT) enzymes. Fevipiprant was metabolized by a number of the enzymes (Supplemental Table 3), with UDP-glucuronosyltransferase 1A3 (UGT1A3), UDPglucuronosyltransferase 2B7 (UGT2B7), and UDP-glucuronosyltransferase 2B17 (UGT2B17) showing the highest activities. Michaelis-Menten enzyme kinetic parameters are shown in Table 5, and the kinetic profiles are presented in Supplemental Figs. 3-5.

To evaluate hepatic uptake, we measured $\left[{ }^{14} \mathrm{C}\right]$-fevipiprant uptake into hepatocytes in the presence or absence of transporter inhibitors. Hepatic uptake clearance was determined to be approximately $10 \mu \mathrm{l} / \mathrm{min} / 10^{6}$ cells (Supplemental Table 4). Uptake was slower at $4^{\circ} \mathrm{C}$ or in the presence of organic anion-transporting polypeptide (OATP) transporter inhibitors, indicating a mixture of passive and active (most likely OATP-mediated) hepatic uptake.

To clarify the transporters involved in hepatic uptake as well as renal, biliary, and intestinal secretion, we measured the uptake of $\left[{ }^{14} \mathrm{C}\right]$ fevipiprant into cells overexpressing the corresponding transporters at a range of fevipiprant concentrations in the presence or absence of inhibitors of these transporters. Based on these data (Supplemental Figs. 6-8), fevipiprant was determined to be a substrate of transporters OATP1B3 (hepatic uptake; $K_{\mathrm{m}}=16 \mu \mathrm{M}$ ), organic anion transporter 3 (OAT3) (renal secretion; $K_{\mathrm{m}}=3.2 \mu \mathrm{M}$ ), and multidrug resistance gene 
A
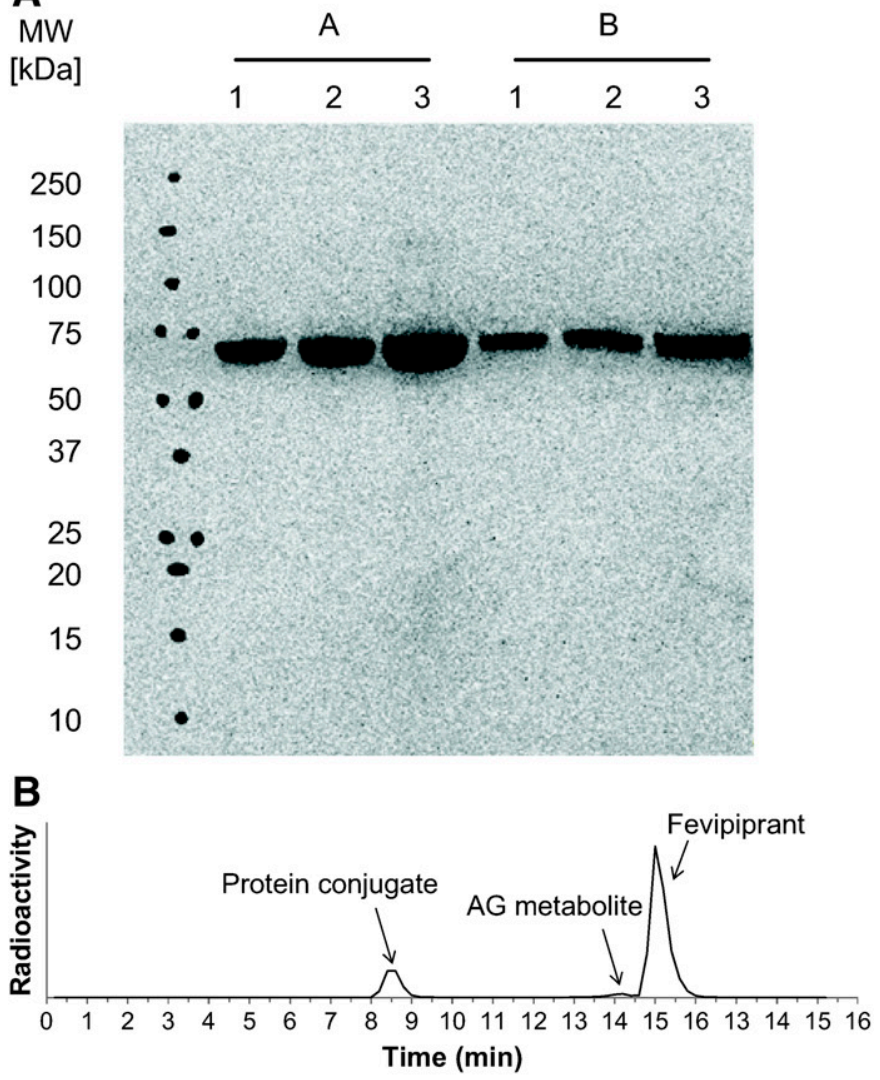

C
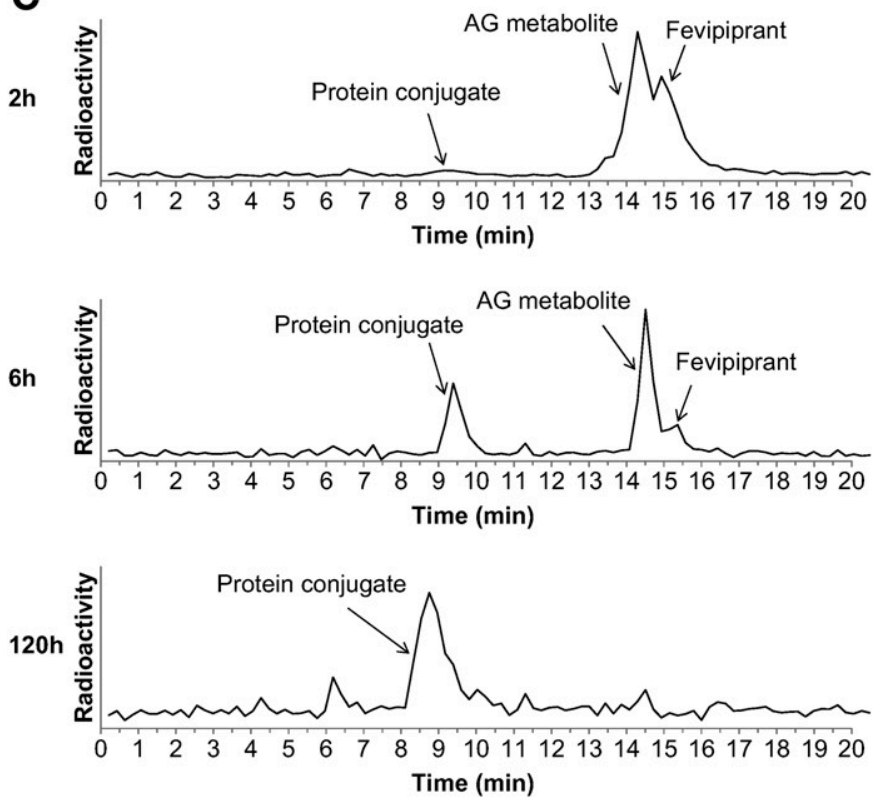

Fig. 5. (A) SDS-PAGE analysis of covalent protein binding after 24 hours of incubation of $\left[{ }^{14} \mathrm{C}\right]-A G$ metabolite $(20 \mu \mathrm{M})$ with $1: 1$ human plasma/PBS at $37^{\circ} \mathrm{C}$. Lanes A1-3: untreated incubation sample; lanes B1-3: incubation sample after albumin depletion using a ProteoExtract Albumin Removal Kit (Calbiochem). Lanes $\mathrm{A} 1 / \mathrm{B} 1, \mathrm{~A} 2 / \mathrm{B} 2$, and $\mathrm{A} 3 / \mathrm{B} 3$ show analyses of 5,10 , and $20 \mu \mathrm{g}$ of protein, respectively. Protein content was determined using a Protein DC Assay (Bio-Rad Laboratories). Relative intensities of bands calculated using AIDA software: A1, 5878; A2, 9787; A3, 17,839; B1, 2791; B2, 6435; and B3, 10,635. The molecular weight markers on the left side of the gel were drawn with ${ }^{3} \mathrm{H}$-supplemented ink to mark the location of visible marker proteins (all blue standard; Bio-Rad Laboratories). (B) SEC analysis after 24 hours of incubation of $\left[{ }^{14} \mathrm{C}\right]-\mathrm{AG}$-metabolite $(100 \mu \mathrm{M})$ with $1: 1$ human plasma/PBS at $37^{\circ} \mathrm{C}$. (C) Representative SEC analyses of
1 (MDR1) (biliary/intestinal efflux; $K_{\mathrm{m}}>200 \mu \mathrm{M}$, exact value not calculable due to lack of saturation), but not a substrate of transporters OATP1B1, OATP2B1, organic anion transporter 1 (OAT1), organic cation transporter 2 (OCT2), multidrug and toxin extrusion protein 1 (MATE1), or multidrug and toxin extrusion protein 2-K (MATE2-K). These data suggest that fevipiprant is actively taken up into hepatocytes by OATP1B3 and actively excreted into bile and into the gastrointestinal tract via MDR1 and into urine via OAT3 transport.

\section{Discussion}

In the present study, the absorption of fevipiprant was estimated to be at least $43.5 \%$, as a minimum estimate based on metabolite excretion and renal fevipiprant excretion. It is likely that the actual absorption value is higher, as AG metabolites would likely hydrolyze to fevipiprant in the gastrointestinal tract after biliary excretion, and in addition direct biliary excretion of fevipiprant is possible. Preclinical data from rats support this hypothesis, with absorption of around $60 \%$, and bile-duct cannulated rat studies after intravenous dosing showing excretion of both fevipiprant ( $25 \%$ of dose) and AG metabolite (33\% of dose) in bile.

The AG metabolite was the only major metabolite detected in plasma. In preclinical species, the AG metabolite was also a major metabolite in plasma and/or excreta but comprised a lower proportion of total plasma AUC $(<30 \%)$. However, in toxicity studies exposure to the AG metabolite at the no-observed-adverse-effect level was similar to or higher than human exposure at the highest phase III dose.

The abundance of the AG metabolite was not well predicted from in vitro data. Although the AG metabolite was formed in hepatocytes of all species investigated (mouse, rat, dog, monkey, human), the calculated intrinsic clearance was in all cases low (e.g., $0.35 \mu 1 / \mathrm{min} / 10^{6}$ cells in human). It is possible that the in vitro underestimation of metabolic clearance is due to reduced activity of OATP1B3-mediated uptake in cryopreserved hepatocyte suspensions in vitro, in comparison with the in vivo situation where transporters are fully active (Lundquist et al., 2014).

Aside from the AG metabolite, we detected a minor lactone metabolite. Due to its low abundance, the formation of this metabolite was not investigated in more detail. However, several possible formation pathways can be envisaged (see Supplemental Fig. 9) involving epoxidation, followed by either nucleophilic ring-closing or epoxide hydrolysis and lactonization. It is unlikely that this possible epoxide intermediate is involved in the formation of the observed covalent adduct in plasma, as the oxidative covalent binding in microsomes and hepatocytes was negligible (Table 4) and relevant reactive metabolites were not detected in plasma.

Total radioactivity was found to decline slowly in blood and plasma after the elimination of the majority of fevipiprant from plasma, likely due to the formation of protein conjugates by covalent binding of the AG metabolite to human serum albumin. The observed terminal half-life of radioactivity in plasma (254 hours or 10.6 days) was in the range of, but shorter than, the half-life reported for human albumin (19 days; Peters, 1996). Consequently, the terminal half-life of total radioactivity, although calculated using data covering a relatively short time period, is likely to be accurate or somewhat underestimated. Preclinical data in rats and dogs show much shorter terminal half-life values for total radioactivity, potentially due to a shorter half-life of albumin in these species (e.g., 2.5 days in rat; Car et al., 2006).

plasma samples from one healthy subject at 2, 6, and 120 hours after oral administration of a $200-\mathrm{mg}$ dose of $\left[{ }^{14} \mathrm{C}\right]$-fevipiprant. 
TABLE 5

Michaelis-Menten enzyme kinetic parameters for biotransformation of fevipiprant by UGT enzymes

\begin{tabular}{lccc}
\hline & UGT1A3 & UGT2B7 & UGT2B17 \\
\hline$V_{\max }($ mean \pm S.D., $\mathrm{pmol} / \mathrm{min} / \mathrm{mg})$ & $5634 \pm 1603$ & $35.2 \pm 6.8$ & $43.3 \pm 0.9$ \\
$K_{\mathrm{m}}($ mean \pm S.D., $\mu \mathrm{M})$ & $13,352 \pm 5854$ & $320 \pm 143$ & $53.3 \pm 4.5$ \\
Derived intrinsic clearance $\left(V_{\max } / K_{\mathrm{m}}, \mu \mathrm{l} / \mathrm{mg} / \mathrm{min}\right)$ & 0.422 & 0.11 & 0.812 \\
\hline
\end{tabular}

The concentration of radioactivity remaining in plasma after 240 hours (500 $\mathrm{pmol} / \mathrm{ml}$ ) corresponds to around $1.5 \mu \mathrm{mol}$ or $0.65 \mathrm{mg}$ fevipiprant equivalent, assuming 3-liters human plasma volume. Assuming that approximately $60 \%$ of albumin is distributed to extracellular space (Peters, 1996), the amount of drug-albumin conjugate remaining in the body at 240 hours after the dose is thus approximately $1.6 \mathrm{mg}$, corresponding to $0.8 \%$ of the dose (or $0.3 \%$ assuming no extravascular distribution of the protein conjugate). Given a total body albumin of around $360 \mathrm{~g}$ (Peters, 1996), the extent of covalent binding is then around $0.07 \%$ of total body albumin. Consequently, repeated dosing with fevipiprant is unlikely to lead to the covalent modification of a large proportion of albumin in the body.

The stability of acyl glucuronides has been previously investigated in detail (Regan et al., 2010). Key factors proposed to be associated with AG stability are steric accessibility and electronic properties of the carboxylic acid/ester functionality. Fevipiprant contains a sterically unhindered carboxylic acid as part of an aryl-acetic acid moiety, similar to diclofenac and tolmetin, which also form unstable AG metabolites (Zia-Amirhosseini et al., 1994; Castillo et al., 1995). It is therefore unsurprising that the AG metabolite of fevipiprant is also unstable.

AG-derived drug-protein conjugates have been observed for other drugs such as ibuprofen and tolmetin, as well as bilirubin (Weiss et al., 1983; Zia-Amirhosseini et al., 1994; Castillo et al., 1995), which has been reviewed extensively (Regan et al., 2010). A number of AG-forming drugs have been associated with clinical AEs such as hepatotoxicity. However, no clear causal link of AEs to the reactivity or covalent protein binding of the acyl glucuronides has been established. In comparison with other covalent binding compounds (Usui et al., 2009), including compounds that form AG metabolites (Darnell et al., 2015), the in vitro covalent binding of fevipiprant to liver microsomes and hepatocytes (Table 4) is negligible. Additionally, no covalent binding to liver microsomes associated with glucuronidation was observed, suggesting that the AG metabolite does not rapidly bind to liver proteins after its formation. From this it can be inferred that covalent binding to albumin occurs in plasma rather than in the liver, likely due to the high concentrations of both AG metabolite and albumin in plasma.

As of January 2017, over 1700 subjects have been exposed to fevipiprant in the clinical program. Phase 3 trials in asthma are currently ongoing. There have been no AEs of idiopathic drug reactions or liver toxicity in these clinical studies. Overall, the in vivo nonclinical assessments and clinical safety data available to date indicate a low risk of idiosyncratic drug-induced liver injury or other idiosyncratic drug reactions potentially associated with covalent drug-protein binding, in line with the apparently negligible reactive metabolites formed by oxidative pathways.

Excretion and metabolism data from this study indicate that fevipiprant is eliminated by several pathways. After oral administration, $57 \%$ of the dose was detected as unchanged fevipiprant in urine and feces, indicating direct renal and possibly biliary excretion. In addition, $29 \%$ of the dose was excreted as metabolites. The exact amounts of dose eliminated by metabolism and direct excretion are not clear, as backconversion of the AG metabolite to fevipiprant during/after excretion is possible. Data from preclinical species (mouse, rat, and dog) showed similar excretion routes, except with relatively higher fecal excretion. In mice, rats, and dogs, fecal/biliary excretion was around $80 \%$ of dose (after both intravenous and oral administration), and renal excretion was $1 \%$ in mice, $6 \%-7 \%$ in rats, and $11 \%-13 \%$ in dogs. Urinary excretion in rats and dogs consisted mainly of the parent drug, suggesting that the higher overall renal excretion in humans is due to a fast renal (rather than biliary) excretion of the AG metabolite, or due to a more extensive formation of AG metabolite in humans, in line with the high plasma concentrations of the AG metabolite.

We demonstrated in vitro that fevipiprant was a substrate of several human UDP-glucuronosyltransferases as well as transporters involved in tubular secretion in the kidney (OAT3), active hepatic uptake (OATP1B3), and biliary excretion (MDR1). The OAT3 data show that the elimination of fevipiprant involves direct renal secretion. This is in line with the measured renal clearance value $(\sim 91 / \mathrm{h})$, which is higher than the expected glomerular filtration clearance $(0.9 \mathrm{l} / \mathrm{h}$, based on a glomerular filtration rate of $7.5 \mathrm{l} / \mathrm{h}$ in Davies and Morris, 1993, multiplied by the fraction unbound $\left[f_{\mathrm{u}}\right]$ of fevipiprant $[0.118]$ ), as expected in the case of active renal secretion. As fevipiprant is a substrate of MDR1, biliary or intestinal secretion is also likely; this would contribute to the large amount of unchanged fevipiprant excreted in feces. The UGT phenotyping data show that at least three hepatic and extrahepatic (Tukey and Strassburg, 2000) UGT isoenzymes are involved in the metabolic clearance pathways of fevipiprant.

Based on the range of elimination pathways and isoenzymes involved in the clearance of fevipiprant, a low risk of DDI or variability due to genetic differences is expected. However, to address possible effects of the inhibition of these pathways on the PK of fevipiprant, clinical DDI studies are planned or ongoing with inhibitors of OAT3, UGT enzymes, OATP1B3, and MDR1. Additionally, the potential of fevipiprant and its AG metabolite to inhibit these or other enzymes and transporters involved in drug disposition has been assessed (Barve et al., 2016).

For the AG metabolite, the renal clearance was similar to fevipiprant $(\sim 8 \mathrm{l} / \mathrm{h})$, and the expected clearance by glomerular filtration is $1.76 \mathrm{l} / \mathrm{h}$ $\left(0.234\left[f_{\mathrm{u}}\right] \times 125 \mathrm{ml} / \mathrm{min}\right.$, as described above for fevipiprant). As the expected glomerular filtration clearance is 5-fold lower than the observed renal clearance, an active tubular secretion of the AG metabolite is also likely.

In conclusion, we demonstrated that fevipiprant is eliminated via various metabolic enzymes and direct excretion, so this novel compound is unlikely to be a victim of a strong drug interaction or to display major variability or ethnic sensitivity in PK due to genetic polymorphism. The major metabolite is an AG that forms covalent adducts to albumin in human plasma.

\section{Acknowledgments}

The authors thank Maxime Garnier, Stephan Utzinger, Claire Adcock, Luu Van Tong, Yves Metz, Matthias Frommherz, Patrick Bross, and Hubert Borell for technical assistance and Karine Litherland, David Sandham, Matthias Kittelmann, Ines Rodriguez, Carsten Bauer, Matthew Brown, Albrecht Glaenzel, Walid Elbast, Jagruti Desai, Paul Goldsmith, Ping Zhou, and Piet Swart for contribution to study design and execution. Delia Randall provided medical writing and editing support. 


\section{Authorship Contributions}

Participated in research design: Jin, van Lier, Erpenbeck, End, Glaenzel,

Woessner.

Conducted experiments: van Lier.

Contributed new reagents or analytic tools: Eggimann.

Performed data analysis: Pearson, Weiss, Jin, End, Glaenzel.

Wrote or contributed to the writing of the manuscript: Pearson, Weiss, Jin, Erpenbeck, Glaenzel, End, Eggimann, Camenisch.

\section{References}

Bailey MJ and Dickinson RG (2003) Acyl glucuronide reactivity in perspective: biological consequences. Chem Biol Interact 145:117-137.

Bala K, Leblanc C, Sandham DA, Turner KL, Watson SJ, Brown LN, and Cox B (2005) inventors, Novartis AG, assignee. Pyrrolopyridine derivatives and their use as CRTh2 antagonists. WIPO patent WO2005123731. 2005 Jun 16.

Barve A, Tillmann H-C, Ilsley E, Vemula J, Nica A, Imbert G, Elbast W, Schiller H, Camenisch G, and Woessner R (2016) Impact of co-administration of fevipiprant (QAW039) and SLCO1B1 genotype on the PK of simvastatin and rosuvastatin (Abstract). Eur Respir J 48 (Suppl 60):1108 DOI: 10.1183/13993003.congress-2016.PA1108.

Car BD, Eng VM, Everds NE, and Bounous DI (2006) Clinical pathology of the rat, in The Laboratory Rat, 2nd ed. (Suckow MA, Weisbroth SH, and Franklin CL, eds) pp 127-146, Academic Press, Burlington, VT.

Castillo M, Lam YW, Dooley MA, Stahl E, and Smith PC (1995) Disposition and covalent binding of ibuprofen and its acyl glucuronide in the elderly. Clin Pharmacol Ther 57:636-644.

Center for Drug Evaluation and Research (CDER) (2012) Guidance for Industry: Drug Interaction Studies-Study Design, Data Analysis, Implications for Dosing, and Labeling Recommendations [Draft Guidance], U.S. Department of Health and Human Services, Food and Drug Administration, Rockville, MD. http://www.fda.gov/downloads/Drugs/GuidanceComplianceRegulatoryInformation/Guidances/ucm292362.pdf.

Center for Drug Evaluation and Research (CDER) (2008) Guidance for Industry: Safety Testing of Drug Metabolites, U.S. Department of Health and Human Services, Food and Drug Administration, Rockville, MD. https://web-beta.archive.org/web/20151015045255/https://www.fda.gov/ downloads/Drugs/GuidanceComplianceRegulatoryInformation/Guidances/ucm079266.pdf.

Committee for Human Medicinal Products (CHMP) (2012) Guideline on the Investigation of Drug Interactions [Final], European Medicines Agency, London. http://www.ema.europa.eu/docs/ en_GB/document_library/Scientific_guideline/2012/07/WC500129606.pdf.

Conference on Harmonisation (ICH) (2009) Guidance on Nonclinical Safety Studies for the Conduct of Human Clinical Trials and Marketing Authorization for Pharmaceuticals M3(R2). ICH Harmonised Tripartite Guideline. 2009 June 11. http://www.ich.org/fileadmin/Public Web_Site/ICH_Products/Guidelines/Multidisciplinary/M3_R2/Step4/M3_R2_Guideline. pdf.

Darnell M, Breitholtz K, Isin EM, Jurva U, and Weidolf L (2015) Significantly different covalent binding of oxidative metabolites, acyl glucuronides, and S-acyl CoA conjugates formed from xenobiotic carboxylic acids in human liver microsomes. Chem Res Toxicol 28:886-896.

Davies B and Morris T (1993) Physiological parameters in laboratory animals and humans. Pharm Res 10:1093-1095.

Ebner T, Wagner K, and Wienen W (2010) Dabigatran acylglucuronide, the major human metabolite of dabigatran: in vitro formation, stability, and pharmacological activity. Drug Metab Dispos 38:1567-1575.
Erpenbeck VJ, Vets E, Gheyle L, Osuntokun W, Larbig M, Neelakantham S, Sandham D, Dubois G, Elbast W, Goldsmith P, et al. (2016) Pharmacokinetics, safety, and tolerability of fevipiprant (QAW039), a novel CRTh2 receptor antagonist: results from 2 randomized, phase 1, placebo-controlled studies in healthy volunteers. Clin Pharmacol Drug Dev 5: 306-313.

Gao H, Jacobs A, White RE, Booth BP, and Obach RS (2013) Meeting report: metabolites in safety testing (MIST) symposium — safety assessment of human metabolites: what's REALLY necessary to ascertain exposure coverage in safety tests? AAPS J 15:970-973.

International Commission on Radiological Protection (ICRP) (2007) The 2007 Recommendations of the International Commission on Radiological Protection. Ann ICRP 37:1-332.

Lundquist P, Lööf J, Sohlenius-Sternbeck AK, Floby E, Johansson J, Bylund J, Hoogstraate J, Afzelius L, and Andersson TB (2014) The impact of solute carrier (SLC) drug uptake transporter loss in human and rat cryopreserved hepatocytes on clearance predictions. Drug Metab Dispos 42:469-480.

Pawankar R (2014) Allergic diseases and asthma: a global public health concern and a call to action. World Allergy Organ $J$ 7:12.

Peters, JrTJ (1996) Metabolism: Albumin in the Body, in: All about Albumin: Biochemistry, Genetics, and Medical Applications, pp 188-250, Academic Press, San Diego, CA.

Regan SL, Maggs JL, Hammond TG, Lambert C, Williams DP, and Park BK (2010) Acyl glucuronides: the good, the bad and the ugly. Biopharm Drug Dispos 31:367-395.

Sykes DA, Bradley ME, Riddy DM, Willard E, Reilly J, Miah A, Bauer C, Watson SJ, Sandham DA, Dubois G, et al. (2016) Fevipiprant (QAW039), a slowly dissociating CRTh2 antagonist with the potential for improved clinical efficacy. Mol Pharmacol 89:593-605.

Townley RG and Agrawal S (2012) CRTH2 antagonists in the treatment of allergic responses involving TH2 cells, basophils, and eosinophils. Ann Allergy Asthma Immunol 109: $365-374$.

Tukey RH and Strassburg CP (2000) Human UDP-glucuronosyltransferases: metabolism, expression, and disease. Аnпи Rev Pharmacol Toxicol 40:581-616.

Usui T, Mise M, Hashizume T, Yabuki M, and Komuro S (2009) Evaluation of the potential for drug-induced liver injury based on in vitro covalent binding to human liver proteins. Drug Metab Dispos 37:2383-2392.

Wang L, Munsick C, Chen S, Bonacorsi S, Cheng PT, Humphreys WG, and Zhang D (2011) Metabolism and disposition of 14C-labeled peliglitazar in humans. Drug Metab Dispos 39: 228-238.

Weiss JS, Gautam A, Lauff JJ, Sundberg MW, Jatlow P, Boyer JL, and Seligson D (1983) The clinical importance of a protein-bound fraction of serum bilirubin in patients with hyperbilirubinemia. $N$ Engl J Med 309:147-150.

Xue L, Salimi M, Panse I, Mjösberg JM, McKenzie AN, Spits H, Klenerman P, and Ogg G (2014) Prostaglandin D2 activates group 2 innate lymphoid cells through chemoattractant receptorhomologous molecule expressed on TH2 cells. J Allergy Clin Immunol 133:1184-1194.

Zia-Amirhosseini P, Ojingwa JC, Spahn-Langguth H, McDonagh AF, and Benet LZ (1994) Enhanced covalent binding of tolmetin to proteins in humans after multiple dosing. Clin Pharmacol Ther 55:21-27.

Zuberbier T, Lötvall J, Simoens S, Subramanian SV, and Church MK (2014) Economic burden of inadequate management of allergic diseases in the European Union: a GA(2) LEN review. Allergy 69:1275-1279.

Address correspondence to: Dr. David Pearson, Pharmacokinetics Sciences, Novartis Institutes for Biomedical Research, Postfach, CH-4002 Basel, Switzerland. E-mail: david.pearson@novartis.com 